\title{
MEDIA PEMBELAJARAN BERBASIS GAME : DAPATKAH MENINGKATKAN PEMAHAMAN KONSEP MATEMATIS ?
}

\author{
Riska Ayu Ardani ${ }^{1}$, Nilza Humaira Salsabila ${ }^{2}$ \\ ${ }^{1}$ Universitas Islam NegeriWalisongo Semarang \\ ${ }^{2}$ Universitas Mataram \\ ${ }^{1}$ Email: riskaayuardani@walisongo.ac.id
}

\begin{abstract}
Conceptual understanding is a basic ability that needs to be built on students' cognitive skills in mathematics learning. The ability of conceptual understanding is a basis for reaching the realm of high-level mathematical thingking. As an effort to improve students' conceptual understanding in society 5.0, teacher must integrate technology in mathematics learning. One use of technology in mathematics learning is game-based learning media. The purpose of this study was to demonstrate the principles and results of using game-based learning mediain mathematics learning to improve students' conceptual understanding. This study used a qualitative method and data were collected through pre test and post test. This study used 5 principles of using gamebased learning media, (1) intrinsic motivation; (2) learning through intense enjoyment and fun; (3) authenticity; (4) self-reliance and autonomy; and; (5) experientasl learning. The results showed that students' conceptual understanding increased significantly although there were some deficiencies.
\end{abstract}

Keywords:Learning Media, Game, Conceptual Understanding

\begin{abstract}
Abstrak
Pemahaman konsep adalah kemampuan dasar yang perlu dibangun pada keterampilan kognitif siswa dalam pembelajaran matematika. Kemampuan pemahaman konsep merupakan dasar untuk mencapai ranah berpikir matematika tingkat tinggi. Sebagai upaya untuk meningkatkan pemahaman konsep siswa di era society 5.0, guru perlu mengintegrasikan teknologi dalam pembelajaran matematika. Salah satu pemanfaatan teknologi dalam pembelajaran matematika adalah penggunaan media pembelajaran berbasis game. Tujuan dari penelitian ini adalah untuk mendemonstrasikan prinsip dan hasil dari penggunaan media pembelajaran berbasis game dalam pembelajaran matematika untuk meningkatkan pemahaman konsep siswa. Penelitian ini menggunakan metode kualitatif diskriptif dan pengumpulan data dilakukan melalui pre test dan post test. Penelitian ini menggunakan lima prinsip penggunaan media pembelajaran berbasis game, (1) motivasi intirinsik; (2) belajar melalui kesenagan yang intens; (3) keaslian; (4) kemandirian dan otonomi; dan (5) pengalaman belajar. Hasil penelitian menunjukkan bahwa pemahaman konsep matematika siswa meningkat secara signifikan mespikun terdapat beberapa kekurangan dalam pelaksanaannya..
\end{abstract}

Kata kunci: Media Pembelajaran, Game, Pemahaman Konsep

Cara Menulis Sitasi: Ardani, R. A., \& Salsabila, N. H. (2020). Media Pembelajaran Berbasis Game : Dapatkah Meningkatkan Pemahaman Konsep Matematis ?.Mathematic Education and Aplication Journal, 2(2), 8-17.

Pemahaman konsep adalah kemampuan dasar yang perlu dibangun sebagai keterampilan awal dalam mempelajari matematika tingkat tinggi (Afamasaga-Fuata'i A.,2008: 8). Siswa tidak mahir dalam pemahaman konsep matematika, maka siswa tidak dapat mencapai kemampapuan berpikir matematis tingkat tinggi (Willingham, 2008: 21). Hal ini juga dijelaskan dalam ranah kognitif Taxonomy Bloom, siswa dapat mencapai kemampuan berpikir tingkat tinggi dimulai dari kemampuan mengingat, memahami, mengaplikasikan, menganalisis, mengevaluasi, dan mencipta (Hyder S. I., 2017: 290). Meninjau bahwa kemampuan pemahaman konsep penting dalam proses belajar 
matematika, maka peran guru dalam meningkatkan kemampuan pemahaman konsep pun dibutuhkan.

Walaupun pendidikan terus berkembang, masih banyak siswa yang gagal dalam belajar matematika. Kegagalan siswa dimulai dari siswa tidak mampu memahami pemahaman konsep matematika dengan baik, sehingga mengakibatkan siswa tidak dapat berpikir pada level yang lebih tinggi. Hal ini terjadi karena siswa merasa kesulitan belajar matematika dengan cara guru mengajar (Krisdiana, 2014: 1). Selain itu, siswa merasa tidak antusias dalam menerima materi matematika melalui media yang tidak variatif (Ardani, 2017: 230). Berdasarkan kondisi tersebut, ada dua hal yang perlu digarisbawahi dalam meningkatkan pemahaman konsep siswa, yaitu bagaimana guru mengajar dan media pembelajaran yang digunakan di kelas.

Mempelajari matematika menggunakan kecanggihan teknologi merupakan tantangan pendidikan di era 5.0. Media pembelajaran berbasis game merupakan salah satu media alternatif berbasis teknologi yang dapat digunakan untuk meningkatkan cara guru mentransfer materi matematika. Media pembelajaran berbasis game merupakan media pembelajaran yang menggabungan dua unsur yaitu, game dan teknologi (Yusof, et. al., 2015: 1239). Ketika guru mampu menghadirkan game dan teknologi ke dalam kelas maka semangat dan minat belajar matematika siswa akan meningkat (Aksakal, N., 2015: 1233).

Media pembelajaran berbasis game bukanlah sesuatu yang baru dalam pendidikan. Namun, faktanya media pemebelajaran berbasis game belum banyak digunakan dalam proses pembelajaran matematika. Mayoritas guru menggunakan media buku atau slide presentasi (Ardani, 2017: 230). Selain itu, guru meyakini bahwa matematika yang abstrak akan lebih tepat dijelaskan secara langsung. Sedangkan dengan mengintegrasikan teknologi dalam proses pembelajaran dapat memberikan pengaruh yang signifikan dalam meningkatkan hasil belajar matematika (Dickey, M.D., 2005: 440).

Beberapa penelitian menunjukkan bahwa media pembelajaran berbasis game memberikan berbagai keuntungan bagi guru maupun siswa (Niston, G.C., 2018: 308). Media ini telah digunakan dalam proses pembelajaran yang ternyata dapat meningkatkan motivasi dan minat siswa dalam belajar (Douadi, B., 2012: 455). Oleh karena itu, tugas guru selanjutnya adalah bagaimana merancang media pemebelajaran berbasis game yang efektif dan efisien yang tidak hanya meningkatkan motivasi dan minat tetapi juga dapat meningkatkan kemampuan berpikir atau kognitif siswa.

Berdasarkan uraian diatas, maka peneliti berupaya mengembangkan dan menerapkan media pembelajaran berbasis game yang dapat digunakan dalam proses pembelajaran matematika. Media pemebelajaran berbasis game yang dirancang peneliti dalam penelitian ini merupakan media yang dapat digunakan pada smartphone dan PC. Game ini merupakan jenis game petualangan dan menyajikan materi matematika (bidang datar). Peneliti mencoba merancang game dengan prinsip pengembangan media yang efektif. Setelah merancang dan mengembangankan media pembelajaran berbasis game, peneliti melakukan penilaian untuk mengetahui apakah kemampuan pemahaman 
konses siswa meningkat atau tidak. Secara garis besar, penelitian ini bertujuan untuk menjawab dua pertanyaan berikut.

1) Bagaimana penerapan media pembelajaran berbasis game secara efektif dalam pembelajaran matematika ?

2) Apakah media pembelajaran berbasis game dapat meningkatkan kemampuan pemahaman konsep siswa?

\section{METODE}

\section{Metode Penelitian}

Penelitian ini adalah jenis penelitian kualitatif. Penelitian ini berupaya memberikan gambaran tentang pronsip-prinsip penerapan media pembelajaran berbasis game di kelas. Sebelum digunakan dalam proses pembelajaran, game divalidasi oleh ahli media dan ahli materi terlebih dahulu. Selanjutnya peneliti juga ingin menunjukkan apakah media pembelajaran berbasis game dapat meningkatkan kemampuan pemahaman konse siswa atau tidak. Prinsip penggunaan media pembelajaran berbasis game diperoleh dari studi literatur pada penelitian sebelumnya. Untuk meninjau kemampuan pemahaman konsep siswa dilakukan tes yaitu pre test dan post test kemudian data dianalisis secara kualitatif.

\section{Subjek Penelitian}

Partisipan yang terlibat dalam penelitian ini adalah 66 siswa SMP yang diambil dari sekolah dengan kategori B (baik). Sekolah tersebut memiliki sarana prasarana yang lengkap, berkualitas baik dan dapat dimanfaatkan dalam proses pembelajaran seperti LCD dan laboratorium komputer. Selain itu, sekolah juga memperbolehkan siswanya umtuk membawa handphone dan boleh digunakan jika diperlukan dalam proses pembelajaran.

\section{Metode Pengumpulan Data}

Penelitian ini memiliki dua jenis data. Pertama, data terkait evaluasi game yang telah dikembangkan atau validasi media. Data tersebut digunakan untuk mengkaji apakah game yang dikembangkan valid atau tidak dalam mengukur kemampuan pemahaman konsep matematika pada materi bidang datar. Data validasi media diperoleh dari hasil angket yang diisi oleh ahli media dan ahli materi. Kedua, data hasil tes kemampuan pemahaman konsep yang diperoleh dari hasil pre test dan post test.

Sebelum peneliti menerapkan media pembelajaran berbasis game di kelas, terlebih dahulu dilakukan uji validasi media. Tujuannya agar game yang digunakan sesuai dengan prinsip media pembelajaran berbasis game. Selain itu, peneliti juga memberikan siswa pre test sebelum proses pembelajaran dimulai menggunakan media game. Pre test dilakukan dengan tujuan untuk meninjau 
sejauh mana pengetahuan dasar siswa berkaitan dengan materi bidang datar. Selanjutnya, dilakukan post test untuk melihat apakah pemahaman konsep siswa meningkat setelah siswa belajar menggunakan media game atau tidak.

\section{Analisis Data}

Data yang diperoleh dalam penelitian ini adalah data validasi media, nilai pre test dan post test. Semua data kemudian dianalisis secara kualitatif. Validasi media ditampilkan untuk meninjau apakah game yang dikemabngan sesuai dengan prinsip media pembelajaran berbasis game yang efektif atau tidak. Hasil pre test dan post test, dimaksudkan untuk mengukur pemahaman konsep matematika siswa. Angket validasi media disusun berdasarkan lima prinsip media pembelajaran berbasis game yang dirujuk dalam penelitian ini, yaitu (1) motivasi intrinsik; (2) belajar melalui kesenangan yang intens; (3) keaslian; (4) kemandirian dan otonomi; (5) pembelajaran berdasarkan pengalaman. Game yang digunakan dikatakan valid jika pada masing-masing aspek tersebut mendapatkan penilaian kategori tinggi dari validator.

Kemampuan pemahaman konsep pada penelitian ini diukur berdasarkan enam indikator, yaitu (1) mengklasifikasikan objek berdasarkan terpenuhinya syarat-syarat yang membentuk konsep; (2) memilih contoh dan bukan contoh dari konsep yang telah dipelajari; (3) menggunakan prosedur dan operasi algoritma tertentu dalam memecahkan masalah; (4) menerapkan konsep dalam pemecahan masalah; (5) menghubungkan berbagai konsep; dan (6) menyajikan konsep dalam berbagai bentuk representasi matematis. Melalui penggunaan media game di kelas, peneliti menemukan bahwa lebih dari $75 \%$ siswa memiliki kemampuan pemahaman konsep dalam kategori tinggi. Kemampuan pemahaman konsep berada pada kategori tinggi ketika siswa mampu mencapai nilai lebih dari 78 baik pada pre test maupun post test.

\section{Prosedur}

Terdapat empat tahapan yang perlu dilakukan peneliti untuk dapat menjawab pertanyaan penelitian ini. Pertama, peneliti mengembangkan game berdasarkan prinsip media pembelajaran berbasis game yang telah dirujuk. Kedua, melakukan uji validasi game terhadap ahli media dan ahli materi. Ketiga penerapam media game dalam proses pembelajaran matematika dengan media game yang telah dikemabangkan. Terakhir, peneliti mengkaji apakah terdapat peningkatan yang signifikan pada kemampuan pemahaman konsep sisswa setelah mengikuti pembelajaran menggunakan media game.

Peneliti mencoba memperhatikan berbagai aspek agar media game yang akan digunakan dapat meningkatkan pemahaman konsep siswa. Pemabahasan sebelumnya telah membahasa bahwa memahami konsep matematika merupakan kemampuan dasar yang penting dalam pembelajaran matematika. Oleh karena itu, peneliti mencoba untuk menekankan pada pengembangan media game yang dapat merangsang pola pikir siswa untuk memahami suatu konsep matematika. Saat ini media 
game mulai berkembang. Namun, kebanyakan hanya berisi latihan soal, atau simulasi ujian yang tentunya tidak memberikan kesempatan kepada siswa untuk mengkonstruk konsep secara mandiri (Douadi, B., 2012: 456).

Media game pada penelitian ini merupakan jenis game adventure (game petualangan) dengan berbagai misi yang bertingkat didalamnya, Media game yang dikembangkan berisi materi matematika bangun datar. Dalam media game ini, peneliti juga menerapkan pendekatan guided discovery learning. Tujuannya untuk mengarahkan alur berpikir siswa sehingga siswa dapat menemukan konsep dan sifat-sifat dari bangun datar secara mandiri. Sebagai upaya agar media game yang akan digunakan dalam proses pembelajaran matematika memiliki kualitas yang sangat baik, maka peneliti mengacu pada prinsip media pembelajaran berbasis game dari Anderson (Perrotta, C., 2013: 9).

1. Motivasi Intrinsik

Motivasi siswa merupakan aspek penting yang harus diperhatikan oleh guru dalam menciptakan situasi pembelajaran (Perrotta, C., 2013: 9). Motivasi yang tinggi pada siswa tentunya memberikan pengaruh terhadap hasil bealajar siswa (Carmichael, C., 2017: 455). Ketika siswa memiliki minat yang kuat maka dampaknuya siswa akan lebih lama terlibat dalam proses belajar dan pada akhirnya mempengaruhi kognitif siswa (Kraft, K.J., 2017:595). Motivasi tidak hanya didapat dari guru secara langsung tetapi dapat dirasakan dari sifat kegiatan yang dilakukan oleh siswa. Media game yang dikemabngan secara alamiah harus memiliki kegiatan yang dapat merangsang motivasi belajar siswa secara terus menerus. Apabila media game yang dikembangkan tidak membangkitkan motivasi secara kontinu, maka motivasi siswa hanya akan muncul di awal kegiatan atau hanya sesaat (Douadi, B., 2012: 456).. Tugas peneliti selanjutnya adalah merancang media game agar menjadi media yang dapat membangkitkan motivasi belajar siswa secara kontinu. Adapun beberapa hal yang peneliti lakukan untuk dapat memunculkan motivasi belajar siswa secara kontinu dan pada akhrinya akan meningkatkan kemampuan pemahaman konsep matematika siswa.

a. Menyusun alur cerita atau misi menarik dalam media game agar siswa tertarik dan antusias untuk menyelesaikan misi game.

b. Menyesuaikan tingkat kesulitan dalam game sesuai dengan karakteristik siswa.

c. Membuat tingkat kesulitan game meningkat secara bertahap.

d. Memberikan reward dan umpan balik.

e. Mendesain game dengan desain grafis yang menarik.

f. Membuat proporsi yang seimbang dan bermakna anatara game dan materi matematika yang disajikan dalam game.

2. Belajar melalui kesenagan yang intens

Meninjau pada poin yang pertama terdapat hubungan timbal balik anatara motivasi dan kesenangan dalam belajar. Keduanya memiliki porsi yang sama, kesengan belajar yang 
intens maka motivasi juga akan hadir secara terus menerus pada disri siswa (Douadi, B., 2012: 456). Penerapan media game dalam penelitian ini memiliki konsep 90\% belajar secara mandiri oleh siswa menggunakan media game dan $10 \%$ guru memberikan penguatan. Porsi belajar secara mandiri akan lebih menyenangkan melalui media game daripada mendengarkan penjelasan guru secara langsung. Kaitannya dengan kemampuan pemahaman konsep terdapat pada bagaimana sisi afektif dibangun terlebih dahulu, afektif siswa meningkat maka kognitif siswa juga akan meningkat (Kraft, K.J., 2017:595).

3. Keaslian

Autentitas dalam ranah ini merupakan wujud kesadaran diri dalam kegiatan belajar tanpa paksaan dari hal lain (guru, nilai, orang tua, dan lingkungan). Prinsip ini berlaku jika prinsip pertama dan kedua mampu dilaksanakan. Secara otomati ssiswa yang merasa senang dilibatkan dalam pembelajaran maka motivasi belajarnya meningkat sehingga tidak merasa tertekan. Peneliti berharap dalam mengaplikasikan media pembelajaran berbasis game semua siswa antusias dan tidak ada yang merasa tertekan dan kesulitan belajar dengan memainkan game di androidnya.

4. Kemandirian dan otonomi

Media game yang dikembangkan dan diterapkan pada proses pembelajaran matematika dalam penelitian ini mengusung tema kemandirian belajar. Media game dapat digunakan oleh siswa tidak hanya di dalam kelas tetapi siswa bebas menggunakannya di luar kelas. Syarat agar siswa dapat belajar mandiri dengan menggunakan game ini, tugas peneliti sebagai pengajar adalah melakukan monitoring. Oleh karena itu peneliti membuat LKS yang harus dikerjakan oleh siswa setiap siswa menyelesaikan satu misi dalam sebuah game. Kegiatan tersebut merupakan salah satu bentuk monitoring peneliti terhadap aktivitas siswa dalam menggunakan game.

5. Pembelajaran berbasis pengalaman

Prinsip terpenting dalam menerapkan media pembelajaran berbasis game adalah memberikan pengalaman langsung kepada siswa. Prinsip ini erat kaitannya dengan bagaimana peneliti dapat meningkatkan pemahaman konsep siswa melalui game. Motivasi dan minat siswa dibangun dari unsur hiburan atau permainan yang muncul dalam game. Sedangkan untuk meningkatkan kemampuan memahami konsep peneliti mencoba menerapkan pendekatan pembelajaran dengan alur permainan. Pendekatan pembelajaran perlu disisipkan agar game yang dikembangkan tidak terfokus pada konten game saja. Game yang dikembangkan ini memiliki misi permainan untuk mencari harta karun dan melawan berbagai musuh kemudian menyajikan materi matematika peneliti dengan menggunakan pendekatan penemuan terpandu. Pada sesi-sesi tertentu siswa akan menjumpai soal-soal terbimbing sehingga pada akhirnya diharapkan mahasiswa menemukan konsep dan properti bidang datar secara mandiri. Inti dari game yang disusun oleh peneliti dapat dilihat pada Gambar 1 


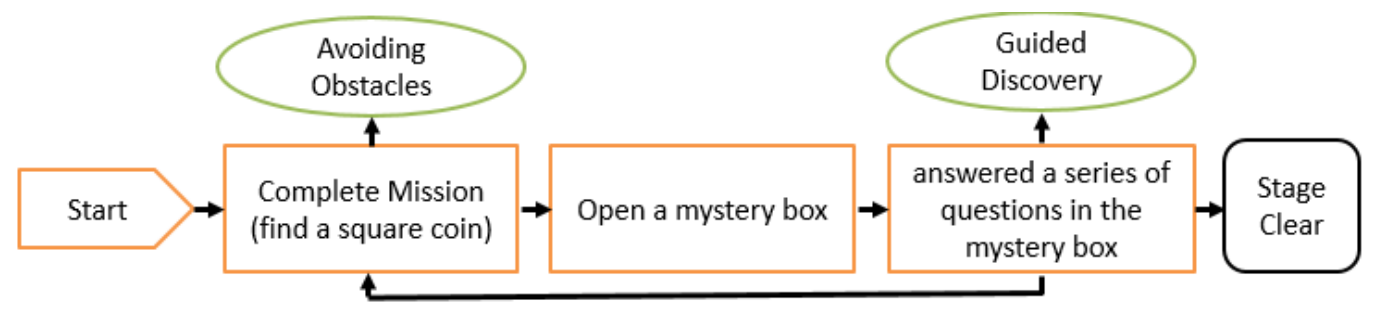

Gambar 1.Desin media game

Prinsip penggunaan media game adalah memberikan pengalaman belajar langsung kepada siswa. Artinya materi tidak dijelaskan oleh guru, tetapi siswa terlibat langsung dalam mengembangkan materi yang dipelajari. Agar siswa tidak merasa kesulitan maka peneliti menerapkan pendekatan penemuan terbimbing. Penggunaan pendekatan penemuan terbimbing dimaksudkan agar siswa mampu belajar secara mandiri dengan bimbingan terstruktur. Pendekatan penemuan terbimbing diyakini dapat meningkatkan kemampuan pemahaman konseptual siswa (Davis, 2017: 77). Hal ini dikarenakan siswa terlibat langsung dalam aktivitas mencari. Ketika siswa merasa kesulitan dalam proses penemuan, peneliti juga mempersiapkan bimbingan kepada siswa. Prinsip panduan yang diberikan dalam game adalah meningkatkan pemahaman konsep sebagai berikut.

a. Membawakan tanggapan atas kegiatan yang dilakukansiswa, yang memberi petunjuk apa yang harus dilakukan bila salah atau benar.

b. Mengarahkan siswa untuk menyimpulkan kegiatan konsep yang dipelajari.

c. Memberikan soal pengayaan dalam media game sehingga dapat melatih pemahaman konsep siswa.

\section{HASIL DAN PEMBAHASAN}

Melalui penelitian ini ditemukan tiga hal penting. Pertama, telah dikembangkan hasil validasi oleh ahli materi dan ahli media terkait media game. Kedua, hasil pre-test siswa sebelum melakukan proses pembelajaran dengan media game. Terakhir, hasil post test siswa setelah melaksanakan pembelajaran dengan media game. Validasi baik oleh ahli materi maupun ahli media dilakukan melalui pengisian angket. Indikator penilaian media game pada penelitian ini dapat dilihat pada Tabel 1.

Tabel 1.Indikator penilaian media game

\begin{tabular}{|c|c|}
\hline Konten Materi & Konten Media \\
\hline Content eligibility & Content quality \\
Presentation eligibility & Learning goal alignment \\
Visual communication & Feedback and adaptation \\
& Affective \\
& Desain Interface \\
& Interaction Usability \\
\hline
\end{tabular}


Hasil validasi oleh ahli materi (A1) diperoleh nilai 107 dari skor maksimal 130. Berdasarkan nilai tersebut maka konten materi yang disajikan dalam media game berada pada kategori baik. Meski hasil validasi oleh ahli materi sudah baik, namun masih ada beberapa hal yang perlu ditingkatkan.

Selain memberi skor, A1 juga memberikan komentar terkait media game yang telah dikembangkan peneliti. A1 mengatakan bahwa "media game Anda pada dasarnya menarik, namun pilihan jawaban pertanyaan yang ditampilkan kurang variatif. Selain itu, terdapat beberapa level yang porsi permainannya lebih besar dari materi yang disajikan.

Hasil validasi oleh ahli media (A2) diperoleh nilai 162 dari skor maksimum 175. Berdasarkan penilaian tersebut, konten media yang terdapat pada game memiliki kualitas yang sangat tinggi. A2 mengatakan "Desain grafis pada media game sangat cocok untuk siswa SMP dan menarik. Namun, masih ditemukan sedikit kesalah penulisan pada media tersebut.

Setelah media dinilai oleh ahli media dan ahli materi, peneliti merevisi apa saja yang perlu ditingkatkan berdasarkan saran dan komentar dari A1 maupun A2. Selanjutnya, peneliti menggunakan media game yang telah direvisi sebagai media pemebelajaran matematika. Peneliti mendistribusikan media game ini pada 66 handphone siswa dan 40 PC di laboratorium komputer pada sekolah penelitian.

Sebelum mengkondisikan aktivitas pembelajaran pada materi bidang datar, peneliti mengadakan pre test pada 66 siswa. Rata-rata hasil pre test pada siswa terkait materi bidang datar adalah 56. Nilai tersebut tentu masih berada pada kategori rendah. Selain itu, nilai tersebut juga merepresentasikan bahwa pemahaman konsep siswa terkait materi bidang datar masih pada kategori rendah.

Proses pembelajaran menggunakan game adalah tujuan utama pembelajaran yang berlangsung Proses pembelajaran dilakukan selama delapan hari. Inti dari apa yang dipelajari menggunakan media game ini adalah, (1) menemukan konsep bidang datar; (2) menemukan sifat-sifat dalam bentuk datar; (3) menemukan rumus luas bidang datar; (4) menemukan rumus keliling bidang datar; dan (5) menggunakan rumus luas dan keliling bidang datar untuk menyelesaikan masalah matematis.

Setelah proses pembelajaran selesai, peneliti memberikan post test kepada siswa. Hasil post test menunjukkan kemajuan yang signifikan. Rata-rata hasil post test 66 siswa adalah 86. Data menunjukkan bahwa $89 \%$ siswa mendapatkan nilai lebih dari 80 . Berdasarkan hasil post test menunjukkan bahwa pemahaman konsep siswa berada pada kategori tinggi.

Hasil analisis data merepresentasikan bahwa game tidak hanya berfungsi sebagai hiburan saja. Namun, game juga memiliki potensi dalam meningkatkan pemahaman konsep siswa. Hasil penelitian Denham (2015) juga menunjukkan hal yang sama bahwa media berbasis game sangat efektif dalam 
meningkatkan kemampuan pemahaman konsep siswa jika media tersebut diorganisir dengan baik (Denham, A.R., 2015:711).

Proses pembelajaran berbasis game memiliki potensi dalam menawarkan pengalaman belajar dalam mempromosikan pembelajaran bermakna (Davis, 2017: 77). Media game yang dikemabangan dalam penelitian ini juga menawarkan ptoses pembelajaran bermakna. Hal ini dikarenakan materi pada game tidak disajikan secara langsung. Untuk mendapatkan informasi, siswa perlu memecahkan beberapa tekat-teki dan tantangan yang dikemas dalam sebuah petualangan dalam game.

Aktifitas belajar menggunakan media game pada penelitian ini telah menggambarkan aktifitas belajar secara kontruktivis melalui media game. Informasi yang dikontruksi sendiir oleh siswa akan menjadi lebih bermakna yang masuk dalam long term memory siswa. Pada akhirnya, secara tidak sadar siswa mampu menggunakan konsep tersebut untuk memecahkan masalah. Beberapa penelitian juga menunjukkan bahwa belajar secara kontruktivis memberikan pengaruh terhadap meningkatnya pemhaman konsep

\section{KESIMPULAN}

Penelitian ini selain mendapatkan suatu fakta terkait penggunaan media pembelajaran berbasis game, juga menghasilkan media game. Media game didesain sebagai media pembelajaran matematika khususnya pada materi bidang datar. Adapun kualitas dan hasil penggunaan media game dalam pembelajaran matematika diuraikan sebagai berikut.

- Hasil penilaian media yang diperoleh dari dua ahli yaitu, ahli materi dan ahli media menunjukkan bahwa media game ini memenuhi kriteria valid dan layak digunakan.

- Media game menjadi efektif dalam penggunaanya karena dikembangkan dengan mempertimbangkan lima prinsip berikut: (1) motivasi intrinsik; (2) belajar melalui kesenangan yang intens; (3) keaslian; (4) kemandirian dan otonomi; (5) pembelajaran berdasarkan pengalaman

- Media game dapat meningkatkan kemampuan pemahaman konsep matematis siswa sehingga dapat dirujuk sebagai alternatif media pembelajaran matematika.

\section{DAFTAR PUSTAKA}

Afamasaga-Fuata'i, A. (2008).Students' Conceptual Understanding And Critical Thinking. Proceedings of the Twentieth Biennial Conference of The Austalian Association of Mathematics Teachers 64(2)pp 8-17.

Aksakal, N. (2015). Theoretical View to The Approach of The Edutainment. Procedia-Social and 
Behavioral Science, pp. 1232-1239.

Ardani, R. A, Salsabila, N. H, Handican, R \&Setyaningrum, W.(2017). The Perceptions of Students and Teachers about The Use of Edutainment Instructional Media in Mathematics Learning Proc. Of The Un of Muhammadiyah Malang's Ist INCOMED228-234.

Carmichael, C., Callingham, R., \& Watt, H.M.G. (2017). Classroom MotivationalEnvironment Influences on Emotional and Cognitive Dimensions of StudentInterest in Mathematics. ZDM Mathematics Education Journal, 49(3), 449-460.

Davis, S., \& Chaile, C. (2017). Implementing A Standards-Based Curriculum In The Early Childhood Classroom : Integrating Math Science through Big Ideas. Routledge: Taylor $\&$ Francis.

Denham, A.R. (2015). Supporting Conceptual Understanding of The Associative and Distributive Properties Through Digital Gameplay. Journal of Computer Assisted Learning, Volume 31, pp.706-721.

Dickey, M.D. (2005). Three-Dimensional Virtual Worlds and Distance Learning: Two Case Studies of Active Worlds As A Medioum For Distance Education. British Journal of Education Technology, Volume 36, pp.439-451.

Douadi, B., Tahar, B., \& Hamid, S. (2012). Smart Edutainment Game forAlgorithmic Thingking. Procedia-Social and Behavioral Science, vol. 31, pp.454-458.

Hyder, S. I. (2017). Bloom's Taxonomy (Cognitive Domain) in Higher Education Settings: Reflection Brief Journal of Education and Educational Development 3(2) pp 288-299

Kraft, K.J. (2017). Developing Students Interest: An Overview of the Research andImplications for Geoscience Education Research and Teaching Practice.Journal of Geoscience Education, 65 (4), 594-603.

Krisdiana, I., Apriandi, D., \& Setiansyah, R.K. (2014). Analisis Kesulitan yang Dihadapi oleh Guru dan Peserta Didik Sekolah Menengah Pertama dalam Implementasi Kurikulum 2013 pada Mata Pelajaran Matematika. Jurnal Ilmiah Pendidikan Matematika Volume3 (No. 1) pp 1-10.

Nistor, G.C., \& Jacob, A. (2018). The Advanteges of Gamification and Game-Based Learning and their Benefits in the Development of Education. The International Scientific Conference eLearning and Software dor Education, Vol. 1 pp. 308-312.

Perrotta, C., Featherstone, G., Aston, H., \& Houghton, E. (2013). Game-based Learning Latest Evidence and Future Directions. Slough: NFER.

Willingham, D. T. (2008). Crtitcal Thingking: Why Is It So Hard to Teach ? Arts Education Policy Review 109(4) pp 21-32.

Yusof, A.M., Daniel, E.G.S., Low, W.Y. \& Aziz, K.A. (2014). Teachers' Perception of Mobile Edutainment for Special Needs Learners: The Malaysian Case. International Journal of Inclusive Education: Cross Mark Volume 18 (No. 12) pp. 1237-1246. 